\title{
PRESS COMMENTS ON THE PEARSON REPORT
}

by Fiona Wilson*

The following British papers carried articles on the Pearson Report: The Times, Financial Times, Guardian, Daily Telegraph, Daily Mail of 2 October; Sunday Times, Observer, Sunday Telegraph of 5 October; New Statesman of 3 0ctober; Economist of 4 October.

Most papers expressed their general support of the report. The Sunday Times stated that the report "perhaps the most authoritative study ever made of this contentious subject, describes a situation which must depress any citizen of the industrialised West capable of thinking beyond the iniquities of his own tax return...." The paper went on to say that: since the US had been "destined to draw in upon itself, the cause of foreign aid needs a proselytising leader. Britain with her extensive programmes and her long experience, is we1l placed to start a revival of international commitment." This should be done through two measures: to raise the aid budget in order to prove that the country intended to reach the target figures for aid, and to write off the unpaid debts incurred by the developing countries.

The Observer agreed that the report "is, as it was described by $\mathrm{Mr}$. Wilson, one of the most important documents of the twentieth century ... The prime contribution made by the Lester Pearson committee is that it has expertly clarified the areas of doubt about the effectiveness and value of aid, exposed the weaknesses of certain practices that have been allowed to grow up and emphasized the overriding need for the developed nations to act a little less greedily...." The Times called it " an historic challenge to both rich and poor countries". The Guardian made the exaggerated statement that the report was 'a bitter indictment of the

*Research Assistant at the Institute of Development Studies. 
failure of the so-called 'development decade' ". In fact the pearson Report had commented on the success of the 'development decade'. The New Statesman said that the Report was "an impressively argued document" and the Daily Mail commented that the report pleaded "the moral case powerfully and argues that it is in everyone's interest that all the world's resources, human and physical, should be put to the greatest possible use".

The Economist picked out one of the Report's recommendations as being of greatest value. The paper thought that the growing numbers of unemployed would become "mankind's biggest danger in the next two decades" and "that is why the most important of the Pearson Commission's many recommendations may well be its urgent plea that the rich countries of the world must start encouraging instead of blocking employment creating exports of manufactured goods from the developing nations". The editorial of the Guardian also found particular points in the Report with which it agreed. The article thought that "a refusal by the rich countries to spend on aid $1 \%$ of their national product by 1975 could produce a nightmare situation. The poor countries are having to find more and more resources ${ }^{2}$ imply to repay the interest on loans, and the profit and dividends on invested capital". The Report "is right in arguing that aid should be increasingly untied" and also correct "in appealing to rich nations to extend more debt relief".

Two of the papers expressed the doubt that the report would receive sufficient attention. The Observer pointed out that "the trouble with historic documents is that they are so seldom heeded at the time ... What makes this particular confrontation [of rich and poor] so dangerous is that it is largely invisible and the arguments over what is possible are so technical. It is difficult to dramatise the crisis and therefore to 'sell' it as a major priority of national policy". The Daily Mail, after summarizing the main points listed in the Pearson Report, declared: "We11, that is all very 
fine, though what effect if will have in countries where more people die of overeating than starvation is fairly easy to guess ... The 400 page Pearson Report is exce11ent but it will fall on many deaf ears - even 10 angels swearing would not at this minute alter the bias of opinions among rich nations." The Guardian read much into McNamara's speech to the TMF-World Bank meeting, stating that "he obviously hoped that it [the Report] will lead to the adoption of a Marshal1-type plan for development".

There were some critical comments made by the press on the Report. The Daily Telegraph thought that the emphasis which was given to official aid "however raises special problems. There is evidence that direct aid, which tends to get filtered through the bureaucracy of the recipient country, is unlikely to be very efficient. There might be some improvement if there were some independent scrutiny of the ways in which the money is actually spent. The need for official aid would be less pressing if more encouragement could be given to foreign private investment. If the poorer countries treated overseas capital fairly, they would get much more of it." The New Statesman gave the warning that: "More important than volume is direction". The Report "calls for more multilateral aid channelled through international agencies. If this means better co-ordination on aid on a more fruitful scale, it is welcome. But it should not mean that any government - and a socialist government in particular - should abandon the responsibilities of giving and of choosing where to give." The Daily Mail pointed out that development does not just mean rising incomes by stating "there is the usual mass of more or less phoney figures which slide over the fact that there is much more to the quality of life than a rising income" Both the Sunday Telegraph and the Daily Telegraph thought that the proposals were unrealistic at the present time (see below) and the Sunday Telegraph also commented that 
"Mr. Edward Boyle" had implied that the Conservatives "would hardly rush to embrace the Report".

Several papers commented on the likelihood of Britain and other donor countries following the proposals of the Pears on Report. The poor performance of the donor countries during the previous decade and the increaaing scale of the problem were mentioned by some articles. Contrary to what the Sunday Times had stated: that Britain should act as a "proselytising leader" in the cause of foreign aid (see above), the Financial Times and the Sunday Telegraph both used the balance of payments argument as an excuse for Britain not reaching the aid targets. The Financial Times stated that the figures quoted were "not an extravagant target and the only decent excuse that countries like Britain can put forward for not hitting it is their balance of payments difficulties". The Sunday Telegraph quoted Jenkins who told the Commonvealth Finance ministers a week earlier that "Britain's balance of payments surplus, strong though it was, couldn't take on anything so demanding as an aid increase get awhile".

The Sunday Telegraph implied that many thought that the target figures proposed were unrealistic. "Sone [of the participants at the IMF World Bank meeting] thought the difficulties made the whole thing unrealistic" and that the Treasury Secretary came as close to saying "forget it as his mormonism would allow". The article suggested that the proposal to increase the resources of the IDA by roughily 4 times the present rate was unlikely because "heaven knows that [the present rate] took enough fighting to get". The Daily Telegraph, implied that it also thought the report was unrealistic by pointing out that "it might not be thought the best of times to confront the richer countries of the world for a fairly massive increase, in aid to the poorer countries".

The following few press comments from overseas that were available at the time of writing can, of course, in 
no way be considered representative of press opinion in their respective countries. They are of some interest, however, and are hence reproduced despite their limited scope.

The International Herald Tribune (October 3) agreed with Fearson's description of the Report as a "sermon on foreign aid" in its "fundamental moral fervor". But since the Conmissio apreciated the difficulties which faced the develofed ountries - "it is therefore a reasoned seimon and not the less powerful for that". The Intexnational Hera1d Tribune of October 6 stated that the report was positive and upbeat (and therefore controversial) in its assessment of the past and its forecast of the future, and it clearly and comprehensively shows how the job [of development] can be done. It points a gassable way toward the reduction of world poverty and the end of aid". The New York Times of october 5 comnented that although the Report did not say anything new, if it "succeeds in reversing the ebb tide of aid, it will be because the Pearson Commission has presented old conclusions with fresh clarity, candor, and conviction and within the compelling context of a broader concept of world community". It thought trat- the Report "demolished"' the nation that aid was a failure. The Christian Science Monitor of October 2 thought that the Report "appears certain to become a standard reference work in the field of development", and that it made a plea for development aid on the basis of "enlightened and constructive self interest".

In the opinion of The New York Times of October 2 "probably the most eloqueil section" was on "Why Aid?". The article thought that "among the more innovative proposals" was the proposal that aid giving countries should use part of the large inflow of interest to subsidise interest rates on some World Bank lending. The New York Times of October 5 considered the Report to be "outspoken in its advocacy" of population control. This contrasted strongly with the 
view of The Internationa1. Herald Tribune of October 6 which was critical on this count, and on one or two others. I* thought that "since it was written not to be admired or even much argued about, but to be acted on, its tone is such as to stimulate government planners and investers, not to offend or discourage them. Hence in one conspicuous instance of misemphasis, it does not give population control the urgent priority it requires". On the subject of the recomnendations, the paper stated that "there are hundreds, not very selectively arrayed". It Further commented that "for a Report like this, its excellence is incidental; implementation is crucial. Implementation falls to others ... that means principally deciding which of the Pearson recommendations require priority application and organising an appropriate onslaught." On the question of the target aid figures it stated that "the US Government, relatively a laggard, now will have to double its efforts". The New York Times of Jctober 5 made a familiar point: the Report is pointed principally at the US, the wealthiest provider and now the biggest backslider among aid-giving nations. The fate of this crucial report and of the world community for which it pleads depends chiefly on the response it evokes in Washington."

The Neue Zürcher Zeitung of 4 October gave a lengthy summary of the Commission's main recomendations, emphasising the suggestions related to the amount and conditions of aid, the debt problen, and the need for greater international cooperation. It called the document "one of the most conprehensive anc thorough studies" on development aid, and suggested the "its repercussions should be felt for a long time". Though the report did not give much evidence of originalizy, it was a careful piece of work, especially noteworthy for having clearly thought through, and suggested solutions for, the problem as a whole. What remained to be seen, however, was whether the report would "manage to avoid the fate of sinilar initiatives, namely its more or less discreet shelving". 
Le Figaro of October 25 reported an interview with Robert Marjolin, a member of the Pearson Gomassion. In his comments, Marjolin spoke of the special importance for the developing countries of the necessary rapid increase in imports of particularly primary goods and improving the texms of trade to be undertaken by the developed world. Le Monde of 18 November carried an article on the Report in which it asked if the "determined optimism" of the report brought aty hope and relief to those who despaired of ever breaking the vicious circles of underdevelopment or of lessening the gulf between rich and poor countries. The Report now had the merit of existing and one could not ignore it. The paper thought the Commission was right in putting at the head of the list of recommendations, the need for liberalising and making more equitable the system of international trade. But after outlining some of the Commissions proposals on international trade, the paper asked ther this was a series of pious hopes. The article thought that it would be on this question that one would judge the strength of the "good will" of the rich countries during the coming decade, and their understanding of what would be needed in the long run, much more than by the volume of their loans and their aid, which had been always more or less "tied" and which as shown elsewhere in the report had led the poor countries into very large debts. The article thought that the Report threw light on the political nature of this aid. Frequently the aid did not help the most intractable problems of the developing countries such as unemployment and under aployment. The article concluded by pointing out that despite it being "global strategy" for development, China had been tacitly excluded.

The Hindu (India) of October 6 thought that the Report " most welcome to the developing countries. It echoes largely their views on the need for a change in present aid practises and the means to achieve that end." It pointed out "that "this is the first time any target date has been suggested for suth a commitment". 
But that "the most interesting part of the Commission's report is its formula for debt relief". The paper was anxious about the attitude of the developed countries and asked: "but will all the aid-givers accept them [the recommendations] or at least agree to give a substantial part of the increased aid recommended?" To reach agreement on multilateral aid schemes will be "tough business", but efforts should be made to persuade countries against tied aid. 